\title{
“The Gifts of the Hurricane:" Reimagining Post-María Puerto Rico through Comics
}

\author{
Daniel Arbino \\ https://orcid.org/0000-0002-1040-3984 \\ University of Texas at Austin, United States
}

\begin{abstract}
Although the media framed Hurricanes Irma and María and their aftermath as a tragedy, and indeed it was, a small literary canon has emerged that explores the storms as an opportunity to rethink Puerto Rico's future. The aftermath of the hurricanes impacted cultural production two-fold; by forcing writers to engage with climate change, while also rethinking the colonial relationship that Puerto Rico has with the United States. Looking specifically at selections from English- and Spanish-language comic anthologies Ricanstruction (2018), Puerto Rico Strong (2018) and Nublado: Escombros de María (2018) as well as single-author graphic novels like María and Temporada (2019), I explore how authors used Hurricane María as a catalyst to reimagine and recreate a more autonomous future for the island through decolonial imaginaries, a notion laid out by Emma Pérez. Despite their different approaches to Puerto Rico's future, the comics' commonality lies in counter-narratives that espouse community values, indigeneity, innovation, and reclamation of nature as a means to confront hardship. Together they produce alternative modalities for transcending the vulnerabilities of debilitating disasters brought on by climate change. They offer a return to pre-colonial values combined with new technologies to empower the island to break from the United States and withstand future storms.
\end{abstract}

Keywords: Decoloniality, Decolonial Imaginary, Puerto Rico, Comics, Graphic Novels, Hurricane María, Tropical Storms, Climate Change

eTropic: electronic journal of studies in the tropics publishes new research from arts, humanities, social sciences and allied fields on the variety and interrelatedness of nature, culture, and society in the tropics. Published by James Cook University, a leading research institution on critical issues facing the world's Tropics. Free open access, Scopus Listed, Scimago Q1. Indexed in: Google Scholar, DOAJ, Crossref, Ulrich's, SHERPA/RoMEO, Pandora. ISSN 1448-2940. Creative Commons CC BY 4.0 free to download, save and reproduce. To cite, include: Author(s), Title of Paper, Editors (Eds.) Special Issue Title (Special Issue) eTropic, volume, issue, year, pages and DOI: http://dx.doi.org/10.25120/etropic.20.2.2021.3815 
eTropic 20.2 (2021) Special Issue: Tropical Imaginaries and Climate Crisis

\section{Opening: Tropical Storms and Decolonial Imaginary}

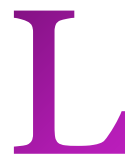

ed by Hurricane Irma and Hurricane María, the 2017 hurricane season will be remembered for the havoc it wreaked, particularly on Puerto Rico. We may never know the true measure of their devastation, but Florido (2019) suggests that conservative estimates place the fatalities associated with the two hurricanes at 3,191 deaths, and estimates in Puerto Rico point to 4,645 for María alone. What is more, damage to buildings, power grids, and potable water sources left the island with long-term challenges. Although the news media framed the storms and their repercussion as a tragedy, and indeed it was, a small canon of cultural production has emerged that explores the storms as an opportunity to rethink the island's future. The aftermath of the hurricanes impacted cultural production twofold; by forcing writers and artists to engage with rising ocean levels and increasingly intense storms, while also rethinking the colonial relationship that Puerto Rico has with the United States. The two topics may seem separate, but the mishandling of recovery efforts reinforced the colonial relationship that Puerto Rico has with the United States, thereby spearheading cultural production grounded in decolonial imaginaries. By a decolonial imaginary, I refer to "a rupturing space, the alternative to that which is between the colonial and postcolonial, that interstitial space where differential politics and social dilemmas are negotiated," as put forth by Emma Pérez (1999, p. 6). This is particularly useful for Puerto Rican cultural production as it navigates the ambiguous spaces of being American, Caribbean, and Latin American at once. Looking specifically at selections from English- and Spanish-language comic anthologies Ricanstruction (2018), Puerto Rico Strong (2018) and Nublado: Escombros de María (2018) as well as single-author graphic novels like María and Temporada (2019)), I explore how authors used Hurricane María as a catalyst to reimagine and recreate a more autonomous political and ecological future for the island. The Puerto Rican comics studied here are decolonial in their perspectives because they make a "conscious effort to retool, to shift meanings and read against the grain" (Pérez, 1999, p. xvii). Despite their different approaches to this ruptured space, their commonality lies in counter-narratives that espouse community values, indigeneity, innovation, and reclamation of nature as a means to confront hardship without relying on some authoritative entity - because they produce alternative modalities for transcending the vulnerabilities of debilitating disasters. They offer a return to pre-colonial values combined with new technologies to empower Puerto Rico to break from the United States and withstand future storms. 
eTropic 20.2 (2021) Special Issue: Tropical Imaginaries and Climate Crisis

The need to envision a future that breaks from the island's current paradigm as an Associated State that is economically and politically dependent on the United States is all the more important since scientists point to an increase in the intensity of natural disasters like hurricanes as a result of global climate change. Wuebbles et. al. (2017) found that "both theory and numerical modeling simulations (in general) indicate an increase in Tropical Cyclone intensity in a warmer world, and the models generally show an increase in the number of very intense Tropical Cyclones" ( $p$. 258). The number of intense hurricanes will grow alongside rising ocean levels, leaving Puerto Rico exposed to further destruction and extensive land inundation because climate change affects the tropics more severely than other regions of the world. At the same time, the United States has demonstrated an inability to successfully manage hurricane cleanup. Thus, although they seem like separate issues, Puerto Rico's ecological vulnerability is inextricably linked to its relationship with the United States - because the latter not only oversees the former's recovery, but is also a major contributor to the processes causing climate change due to widespread industrialization and excessive carbon emissions. Therefore, comic authors that reimagine Puerto Rico's future often do so through a commentary calling for more autonomy in conjunction with promoting green initiatives that will combat climate change.

Although the works I analyze are related to a natural disaster, aspects of the US-led post-María recovery efforts were entangled in a colonial system that led to a humanmade disaster. Etkin (2015) defines disasters as having "historical and cultural roots and need[ing] to be understood in context. They affect people differently, depending on culture, class, race, socioeconomic status, worldview, and psychology" (p. xxi). In agreement, Torres (2019) avers that "the story of Puerto Rico cannot be told without reference to Western modern catastrophe and coloniality" (p. 337). To his point, the US-led mismanagement of the recovery can only be understood within the colonial context. Since the United States took possession of Puerto Rico in 1898, the former has oppressed the latter on their own soil. Arbino (2017), Vargas Morales (2003), and McCaffrey (2002) point to the military using Vieques as an experimental site for chemical warfare like Agent Orange and napalm from 1941-2003. During the decades-long presence, cancer rates soared among local residents who regularly confronted military aggression. ${ }^{1}$ Lopez (2008) and Garcia (1982) have shown the eugenics-led mass sterilization of one-third of Puerto Rican women carried out by the United States in the 1950s and 1960s. Ayala and Bernabe (2007) detail how Operation Bootstrap galvanized the island's economy through industrialization in the

\footnotetext{
1 The Puerto Rican island of Culebra also endured a military presence until 1975.
} 
eTropic 20.2 (2021) Special Issue: Tropical Imaginaries and Climate Crisis

late 1940s, but by the 1960s had seen an increase in unemployment, mass migration, and an overhaul of the traditional agrarian sectors. In the case of Hurricane María recovery efforts, the US again wielded its oppressive power: from downplaying the number of deaths, to weekly power outages, to the delayed distribution of funds and goods (Coto, 2019). Disaster cleanup served as a metaphor for the long processes of slow, structural violence. Perhaps no example better articulates this slow violence than President Trump mocking the destruction by tossing paper towels to a crowd. Puerto Ricans face a hegemonic system where colonialism is constitutive and continuing, but rarely understood as colonialism because it is presented in the guise of terms like "territory" or "Free Associated State." These terms complicate decolonization, here defined as "the process of revealing and dismantling colonialist power in all its forms" (Ashcroft et al., 2010, p. 56). Regarding Puerto Rico, decolonization is all the more complex because the island is a part of the United States, however ambiguously, and its residents are citizens. In other words, although there have been movements for independence, there has been no independence to formally initiate decolonization.

Whereas decolonization is marked by a temporal period in which increased autonomy occurs, decoloniality can, and often expresses liberatory thinking within a hegemonic episteme. It considers differences in histories, social practices, values, beliefs, ideas, and identities, as part of a variety of approaches that subvert coloniality via disobedience. Maldonado-Torres (2007) identifies the process as the decolonial turn, or "a shift in knowledge production" that "introduces questions about the effects of colonization in modern subjectivities and modern forms of life as well as contributions of racialized and colonized subjectivities to the production of knowledge and critical thinking" (pp. 261-2). For Maldonado-Torres, the lasting institutions and legacies of colonialism is what characterizes "coloniality of being" (p. 252). Therefore, decoloniality is defined as "a program of de-linking from contemporary legacies of coloniality" (Mignolo 2007, p. 452) and works to unsettle how colonialism structures the lives of the colonized through Western constructs of class, race, and gender. Moreover, colonial institutions and their legacies actively attempt to erase traditional or non-Western modes of thinking (Lugones 2010, p. 13). According to Mignolo (2005), this epistemological violence in turn creates a colonial wound (p. 8). And, as Mignolo and Vasquez (2013) claim, decoloniality and cultural production work toward disrupting coloniality through "the unveiling of the colonial wound and the possibility of healing." Therefore, Puerto Rican comics not only refute the imposition of coloniality on the imagination, they also offer counter-narratives of healing and autonomy through that interstitial space as outlined by Pérez. 
eTropic 20.2 (2021) Special Issue: Tropical Imaginaries and Climate Crisis

These decolonial approaches have surfaced since María in contemporary art, children's literature ${ }^{2}$ and, as I show below, comics. In his study on decolonial aesthetics in Puerto Rican contemporary art, Rivera-Santana (2020) refers to these approaches as indicative of calls for independence. He writes that:

This aesthetics of disaster processes socio-political realities by expressing the clashing realities of a history of colonization that is dramatically thrown into reprieve by the natural and subsequent tragic human disaster in Puerto Rico. This artistic expression attempts to express Puerto Rican potential to survive as a nation of people, and, at the same time, calls for an end to any form of 'benefit' from the protectorates of the State in Puerto Rico and the State in the United States (p. 346).

Seeing the United States fail them in terms of recovery, Puerto Rican writers and artists are using the aftermath of María to reconfigure the island's future from their own perspectives. Aldama (2009) agrees that "the visual and verbal telling of a comic book story in the present can recall a past (from the present moment of telling) or predict a future; such telling involves centrally readers capable of imagining a present, past, and future different from their present" (p. 105). Specifically, the contemporary deployment of hurricane comics is useful in exploring how groups make meaning of their lives and calamities. One approach to this is through a lens of trauma. Little scholarly research has been done on post-María comics pertaining to Puerto Rico, however, an exception is María Fernanda Díaz Basteris (2019). Through a framework that blends the post-colonial criticism of Knowles (2015) and Ward (2015), with trauma studies in comics as examined by Earle (2017), her analysis focuses on how Puerto Rican webcomics produced by women create a space for gendered critiques of the United States' mismanagement of the island, particularly their hurricane relief efforts. I will be looking at some of the same webcomics that Díaz Basteris interrogates, though my analysis also considers English-language comics edited by people of Puerto Rican descent as well as Spanish-language comics penned by Puerto Ricans. Although many comics address the trauma that stemmed from Hurricane María, I hope to move beyond the lens of trauma and examine texts that approach the hurricane through a decolonial lens of reclamation, self-reliance, and recovery as methods to confront future climate change.

\footnotetext{
${ }^{2}$ For children's literature, see Torres and Medina (2021).
} 
eTropic 20.2 (2021) Special Issue: Tropical Imaginaries and Climate Crisis

\section{Comic Relief: English-Language Anthologies and Humanitarian Aid}

An outpouring of cultural production, both on the island and off, followed Hurricane María. Two such publications were Puerto Rico Strong and Ricanstruction, Englishlanguage graphic novel anthologies that were published in the United States and tied to philanthropic endeavors. They had major distributors like Amazon and Barnes and Noble that broadened their accessibility and dissemination. In turn, their audience was larger, and their cause more attention-grabbing. Building off the success of his superhero series La Borinqueña, author Edgardo Miranda-Rodriguez's edited benefit anthology Ricanstruction was published in May 2018 with 100\% of the proceeds going to help Puerto Ricans on the island with solar-powered lamps, food, and clothing. $^{3}$ As of September 2020, the book had raised more than $\$ 165,000$ in humanitarian aid, which Miranda-Rodriguez used to fund $\$ 10,000$ micro-grants to island-based organizations that are dedicated to reef conservation, climate change, literacy instruction, and woman-focused family education (La Borinqueña grant awardees, 2018). These organizations symbolize the author's vision of the island's future in which small grassroots organizations work directly with the community (Castelblanco, 2018). Miranda-Rodriguez's anthology of sixty-eight original entries (comics and pin-ups) includes contributions from high-profile writers and celebrities: Puerto Ricans Rosario Dawson and Gabby Rivera both penned stories. ${ }^{4}$ In fact, DC comics permitted Miranda-Rodriguez to utilize several of their canonical heroes for the cause: Batman, Superman, Wonder Woman, Aqua Man, and the Flash make appearances alongside Miranda-Rodriguez's superhero La Borinqueña. Plots featuring renowned superheroes are sure to attract a larger mainstream audience, thereby garnering more financial support. On the one hand, the narratives' intentions show solidarity between Puerto Rico and mainstream America and La Borinqueña's presence in this anthology is instrumental to island representation because she navigates New York and Puerto Rico with ease in an outfit that evokes the Puerto Rican flag. On the other hand, the dependency on the DC superhero, often depicted as an outsider with strong ties to the United States, reinscribes a hierarchical power relationship when set alongside the local population in need of saving. However, not all the short narratives in this anthology fall into this formula of messianic superheroes. I am interested in narratives that underscore the power of the people because it is in their resiliency and community-organizing that I find narratives that shift the paradigm.

\footnotetext{
${ }^{3}$ Miranda-Rodriguez (2016 and 2018a) published two volumes of La Borinqueña prior to Ricanstruction.

4 I refer to the works “¡Pa'lante!," and "\#Queerborinegra."
} 
eTropic 20.2 (2021) Special Issue: Tropical Imaginaries and Climate Crisis

Figure 1. Tristan Tarwater's "Pasitos grandes"

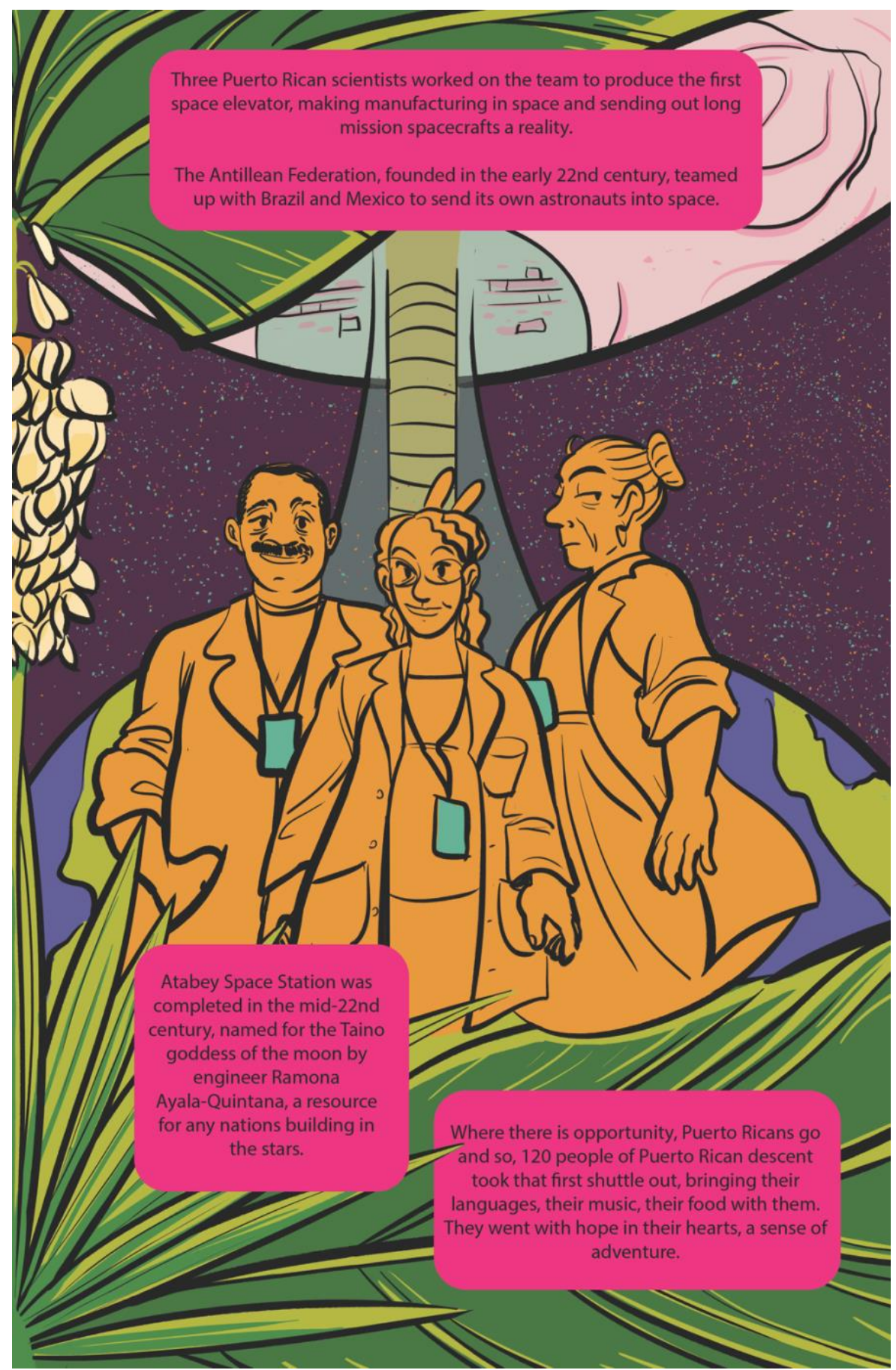

The comic incorporates technological innovation into Puerto Rico's decolonial future. In this imaginary science and tropicality meet. From "Pasitos grandes," by T. Tarwater, 2018, in M. Lopez, D. Rodriguez, H. Newlevant, D. Ruiz, \& N. Schwartz (Eds.), Puerto Rico Strong, p. 39. Copyright 2018 by Oni-Lion Forge Publishing Group. Reprinted with permission. 
eTropic 20.2 (2021) Special Issue: Tropical Imaginaries and Climate Crisis

Alexandra Román's "Thirty years later" (2018) is an intergenerational story in which a grandmother and granddaughter sit near a fallen tree and converse about the transformations that Puerto Rico underwent in the thirty years after Hurricane María. These transformations, accompanied by illustrated flashbacks, were in concert with nature and include exchanging "power grids for solar energy" (p. 156) and "wooden houses for ecological structures" ( $p$. 156) that can withstand future hurricanes. The ecological structures reflect an understanding that local architecture must prepare for future hurricanes by developing new permanent models for building construction. In other words, Román asserts that the current model of building structures, and rebuilding them after a damaging hurricane, must change due to storm-intensity going forward. The age range of the two characters is relevant in conveying this message. The granddaughter is not old enough to remember what Puerto Rico was like prior to Hurricane María, so she relies on her grandmother's maternal wisdom to guide practical living as a means to recover knowledge. The grandmother character is significant because of her role in Puerto Rican families as a marker of cultural continuity. Her mere presence in the household disrupts the American notion of the nuclear family. As a cultural repository, she holds and shares the family's history and she communicates the family and community's values as models to shape younger generations (Olmedo, 2002, p. 36). As a community elder, the grandmother has access to local knowledge, and by passing it on orally, tells how living on the island has improved. Those improvements are decolonial in nature: moving toward ecofriendly forms of energy embraces conservation while eliminating the exploitation of fossil fuels that countries like the United States promote at unsustainable levels. At the same time, moving away from "wooden houses" recalls the long history of deforestation that has taken place throughout the Caribbean. This salient imagining of the future of Puerto Rico implies a divergent path from its current dependent relationship with the United States.

Elizabeth Yeampierre's "Bohio Girasol 2050" (2018) also takes place in the future and has a similar trajectory toward local, grassroots organization. She refers to 2017 as the painful birthing of a new and determined society that would cease to be subjugated by the superpower that had cast its oppressive shadow on the island for hundreds of years (Yeampierre, 2018, p. 164). The declaration reshapes how one thinks about Hurricane María, shifting it from a tragedy to an opportunity to restart. Similar to "Thirty Years Later," the story is structured around multiple generations working together. In "Bohio Girasol 2050", a larger community details how elders pass on knowledge in farming, permaculture, healing, solar energy, water desalinization, and midwifery to apprentices who will carry on the work. The passing of knowledge from elders to younger generations is key to healing colonial wounds, 
eTropic 20.2 (2021) Special Issue: Tropical Imaginaries and Climate Crisis

according to Medina (2014), "because it is a way of knowing and being in the world that values community and understands our interdependency" (p. 169). The story shares that climate change has devastated the North, causing hunger and violence. It is unclear how the tropics avoided similar perils, especially given that scientists predict the tropics to feel the brunt of climate change first. However, this clever inversion of models juxtaposes the island and the Global North through a commentary on land. Yeampierre remarks that those in the Global North "stopped paying attention to land they and their ancestors had extracted for generations" thereby allowing "people of African and Indigenous origin to reclaim their land and long forgotten traditions" (2018, p. 167). This paves the way for Puerto Rico, and other lands that comprise the tropics, to reverse global power dynamics and reclaim lands and knowledge once lost to them. Moreover, the story suggests that children learn through apprenticeships rather than attending school - an institutionalized site of colonial power. In this future, education is kept at a local level, focused on applied methods that strengthen people's connection to the land, and by extension, their culture's values and traditions. Presumably, local history would be taught rather than disconnected, colonial American history. Finally, the presence of La Borinqueña necessitates a comment. Throughout Ricanstruction, Miranda-Rodriguez's superhero appears and saves distressed civilians. However, in "Bohio Girasol," silence characterizes La Borinqueña's presence. The community welcomes her, yet they do not need her. She is a witness to the innovation taking place. Yeampierre contests the over-reliance on one person to play savior and opts to promote community-based knowledge through local culture.

Taking up a similar theme, Sandra Guzman's "My beloved Borikén” (2018) describes a narrator who lives in the Global North to postulate that Puerto Ricans have become disconnected from their Taíno ancestors throughout history, particularly due to Spanish colonization. In her inversion of colonial discourse, she presents the Taínos as "noble and valiant" (p. 100), while describing the Spanish as "sickened with greed" (p. 100). Due to colonialism, Guzman claims that Puerto Ricans have lost their identity and connection to the island. Therefore, Spanish colonialism is the disaster, not Hurricane María. The hurricane provides a rupture to return to autochthonous ways of living. To that end, the author evokes a discourse of nativism from below. According to Coker (2015), nativism from below "is an attempt to preserve or rehabilitate Indigenous culture in opposition to assimilating imperial/colonial culture" (p. 15). Guzman begins reclaiming Taíno cosmovision when she moves away from Catholic monotheism, and instead praises a variety of gods who are expressions of nature: Ata Ey, goddess of the earth, moon, fresh waters, sea and fertility; Cagauana, goddess spirit of love; Juracan, the god of wind, 
eTropic 20.2 (2021) Special Issue: Tropical Imaginaries and Climate Crisis

etc. Recalling Taíno beliefs, she reminds the reader that "The Gods and Goddesses of Boriken are merciful" (p. 102) because their acts, such as hurricanes, are not tragedies, but an impetus for positive change. In that vein, Guzman writes that "these are the gifts of the hurricane, to reimage the island with harmony and respect for all things large and small" (2018, p. 104). The respect for all things large and small acknowledges traditional knowledge in which every species plays a role in maintaining ecological health. The call to embrace pre-colonial beliefs after María is decolonial because it permits populations to reconnect with their traditions and values while moving away from those that the colonizer imposed upon them. The author includes within those values songs to honor nature, a chance for children to play innocently, multigenerational knowledge, and a balanced ecosystem that provides through agriculture and fish (pp. 101-102). The example of fish is particularly significant because the author comments how "nothing is wasted," an allusion to the excesses of late capitalism and overfishing. In that vein, "waste" leads to a disequilibrium in the relationship between humans and nature, but the hurricane provides a rupture from imposed practices. Through the rupture the community transforms by remembering traditional ways. In that sense, collective memory is a channel to reimagine new possibilities and seek rebirth. The fact that the narrative's last lines are in the Taíno language demonstrate the author's intention toward recovery. Here Guzman presents two different perspectives. The pre-colonial perspective offers a healthy lifestyle, community, and an overall sense of interconnectedness between humans and the environment; whereas her reference to the era of US colonialism features expressions like "we have lost our way" ( $p$. 102). and a protagonist who complains of a "foggy mind" (p. 102), that emphasize a sense of disorientation. The aftermath of a disaster like Hurricane María, then, symbolizes an opportunity for restorative ecological balance wherein the community can exact greater agency and return to its preferred lifestyle. Additionally, Guzman offers a sort of environmental nativism wherein a return to pre-colonial ways seemingly reverses climate change, or at the very least, reframes perspectives on tropical storms.

Despite not carrying the same star-studded roster as the comic anthology Ricanstruction, or the crossover opportunities into the DC universe, the collection Puerto Rico Strong offered forty-one unique stories in comic form from different Puerto Ricans both on the island and the US mainland. It also donated all proceeds to the United Way of Puerto Rico and Lion Forge matched the first $\$ 25,000$ in sales with pledges to health-care, child-care, and education (Betancourt, 2018). The majority of the content addressed Hurricane María, however, other stories ranged from first encounters between the Taínos and Europeans to the United States' efforts 
eTropic 20.2 (2021) Special Issue: Tropical Imaginaries and Climate Crisis

to sterilize Puerto Rican women. ${ }^{5}$ Within the scope of this paper, I will consider the comics by Morillo (2018) and Tarwater (2018) for their decolonial engagement with recovery.

Javier Morillo's "Macondo, Puerto Rico" borrows its title from the fictitious Colombian town that serves as the setting for many of Gabriel García Márquez's works. By evoking Macondo, Morillo creates a parallel between it and Puerto Rico. In García Márquez's works, Macondo is an isolated town that becomes exposed to the outside world by foreign economic interests. It is precisely these interests that cause the town's demise. The allusion is an accurate one as Puerto Rico's perpetual colonial status has left it vulnerable to economic interests that have exploited it under the plantation system (sugar, coffee) while at the same time positioning it within the global economy. In García Márquez's One Hundred Years of Solitude (1967), a rain that lasts four years devastates the town, causing many of its residents to depart. Although Hurricane María was much swifter in its damage, the comparisons are not lost, as many people have fled the island. In fact, Morillo's character begins the comic living outside of Puerto Rico, praying the Rosary as María touches down. In contrast to Guzman (2018), who viewed Catholicism as an extension of Spanish colonialism, Morillo identifies Catholicism (represented by the Rosary) as a symbol of resistance to the Protestant values espoused during US colonialism. Therefore, by "re-learning" to pray the Rosary (2018, p. 162), the protagonist is subverting the United States' value system.

"Macondo, Puerto Rico" contextualizes Puerto Ricans' pathway to American citizenship, and later, the ability to vote in presidential elections made available to those living on the US mainland. This information is given to us through flashbacks and through a juxtaposition between a Puerto Rican living on the mainland (the protagonist) and a Puerto Rican living on the island (his college friend lleana). Through historical and contemporary examples, he recounts the many abuses that the US government has inflicted upon Puerto Ricans. Morillo views the US's mishandling of the post-María cleanup as a continuation of this abuse:

I see the dreadfully slow recovery and wonder why we don't have a plan. We know what Wall Street wants to make of Puerto Rico. Prioritize bank debt over people, lower minimum wage, turn the island into a playground for the rich, like Cuba in the 1950s (2018, p. 161).

\footnotetext{
${ }^{5}$ For colonial stories, see Ayala (2018) and Rosado (2018). For sterilization stories, see Rivera (2018) and Shwed (2018).
} 
eTropic 20.2 (2021) Special Issue: Tropical Imaginaries and Climate Crisis

The use of "we" distinguishes Puerto Rico from the United States, signifying that the colonizer and the colonized do not share similar goals for the island's future. The United States seeks to manipulate the disaster to maintain its colonial enterprise through economic stagnation and dependence. In this model, Puerto Ricans will ultimately participate in the tourism sector, which is another form of colonialism that creates a subservient population. Morillo urges Puerto Rico to break from this vertical relationship and strategize initiatives that more directly benefit Puerto Ricans. His work culminates with a series of rhetorical questions stemming from post-María recovery that emphasize an alternative plan that both moves away from Western approaches to energy and economy and allows for long-term survival: "Why weren't we ready to replace coal with sustainable power? Can the island once again produce food for itself? What is our answer to disaster capitalism?" (2018, p. 161). Morillo's implied answers assert that the island's decolonial efforts are tethered to survival through green initiatives and local sustenance as opposed to importing energy and food from the mainland. The mention of coal points to a commentary on climate change, given that fossil fuels are major contributors to rising global temperatures. Although tropical countries like Costa Rica have committed to eliminating fossil fuels in an effort to reduce their footprint, the United States has continued large-scale use, putting Puerto Rico in a precarious position because of its dependency on the United States, coupled with their location in a region directly threatened by increasing temperatures and rising ocean levels. Morillo's call for Puerto Rico to adopt green energy would ultimately create goodwill among its regional neighbors in an effort to stem climate trends.

Tristan Tarwater's "Pasitos grandes" (2018) is set at the Atabey Space Station in 2062 where a guide uses advanced technology to give students a visual tour of Puerto Rican history from the pre-colonial era to the present. Commenting on pivotal themes in Puerto Rican history (Spanish colonization, American colonization, industrialization, mass exodus, and economic hardships), the tour moves into postMaría. Calling the United States' efforts “abysmal” (p. 36), Tarwater looks toward grassroots initiatives that repaired the island through aid and proper resourcedistribution (p. 37). The apparent success of community cleanup spurred additional decolonial initiatives in the comic that end Puerto Rico's economic dependency on the United States. For example, a repeal of the 1917 Jones' Act improves Puerto Rico's economy, making it attractive for eco-friendly companies to come to Puerto 
eTropic 20.2 (2021) Special Issue: Tropical Imaginaries and Climate Crisis

Rico and hire Puerto Ricans to implement renewable energy and technology (p. 38). ${ }^{6}$ Island advances in terraforming "traditional foods" position Puerto Rico as agricultural leaders, making them ideal candidates to carry out similar projects on the moon (p. 38). In this future, Puerto Rico's decolonial status is buttressed by economic liberation and a blending of traditional ways with new technologies. This idea of Puerto Rican futurism pushes beyond independence to imagine Puerto Rico as a leader in green energy initiatives and also a member of the Antillean Federation (p. 39). The very fact that this tour is being conducted via virtual reality from a space station highlights the advances that Puerto Rico has made since gaining independence, but it is the Antillean Federation that adds a significant intervention to this work. The possibility of a connected Caribbean speaks to a movement away from vertical relationships based on previous colonial arrangements (i.e. US-Puerto Rico, The Netherlands-Curaçao) and privileges horizontal relationships within the region that would benefit from new economic opportunities that would follow the aforementioned end to the Jones Act. ${ }^{7}$ Tarwater's decolonial vision, like others in these anthologies, is tied to environmental balance and a reconnection to the past that provides a foundation of continuity for an inventive future. However, the author's departure lies in the elaboration of Morillo's implicit concept of a more unified insular region that can confront and manage glocal concerns, like climate change, together.

\section{The West Indies: Independent Comics for Independentistas ${ }^{8}$}

Puerto Rico Strong and Ricanstruction enjoyed large print runs, mainstream audiences, and publicity. However, independent Puerto Rican graphic novelists and comic strip artists engaged with Hurricane María in other ways, often through smallscale self-publication. ${ }^{9}$ Readers seeking these materials would find them on individual website stores. Moreover, most of the small-scale comics are in Spanish, thereby addressing a different, more local audience. As a result, the authors usually articulate calls for greater autonomy through intimate relationships and insights.

\footnotetext{
6 Yglesias (2017) summarizes the Jones Act as a shipping regulation law that has economically debilitated Puerto Rico because any goods being shipped to Puerto Rico from the United States (or vice versa) must be done so on an American-built ship that is crewed by U.S. citizens or permanent residents.

7 Arbino (2019) foregrounds horizontal relationships in cultural production by placing Curaçaoan writer Tip Marugg alongside regularly recognized gothic writers like Jamaica Kincaid, Mayra Montero, and René Depestre with the aim to increase dialogue among the linguistic blocs of the Caribbean and to avoid a strict framing of literary output within colonial relationships.

${ }^{8}$ Although these other works address Hurricane María, I am not considering them within the scope of my paper either due to content or creator background: Sato by Jordan Clark, It Also Rains in Puerto Rico (2018) by lan Nose, and After María: Everyday Recovery from Puerto Rico (2019) by Gemma Sou.

9 The following works are originally in Spanish. All translations are mine.
} 
eTropic 20.2 (2021) Special Issue: Tropical Imaginaries and Climate Crisis

Figure 2. Rosa Colón's María (2018)
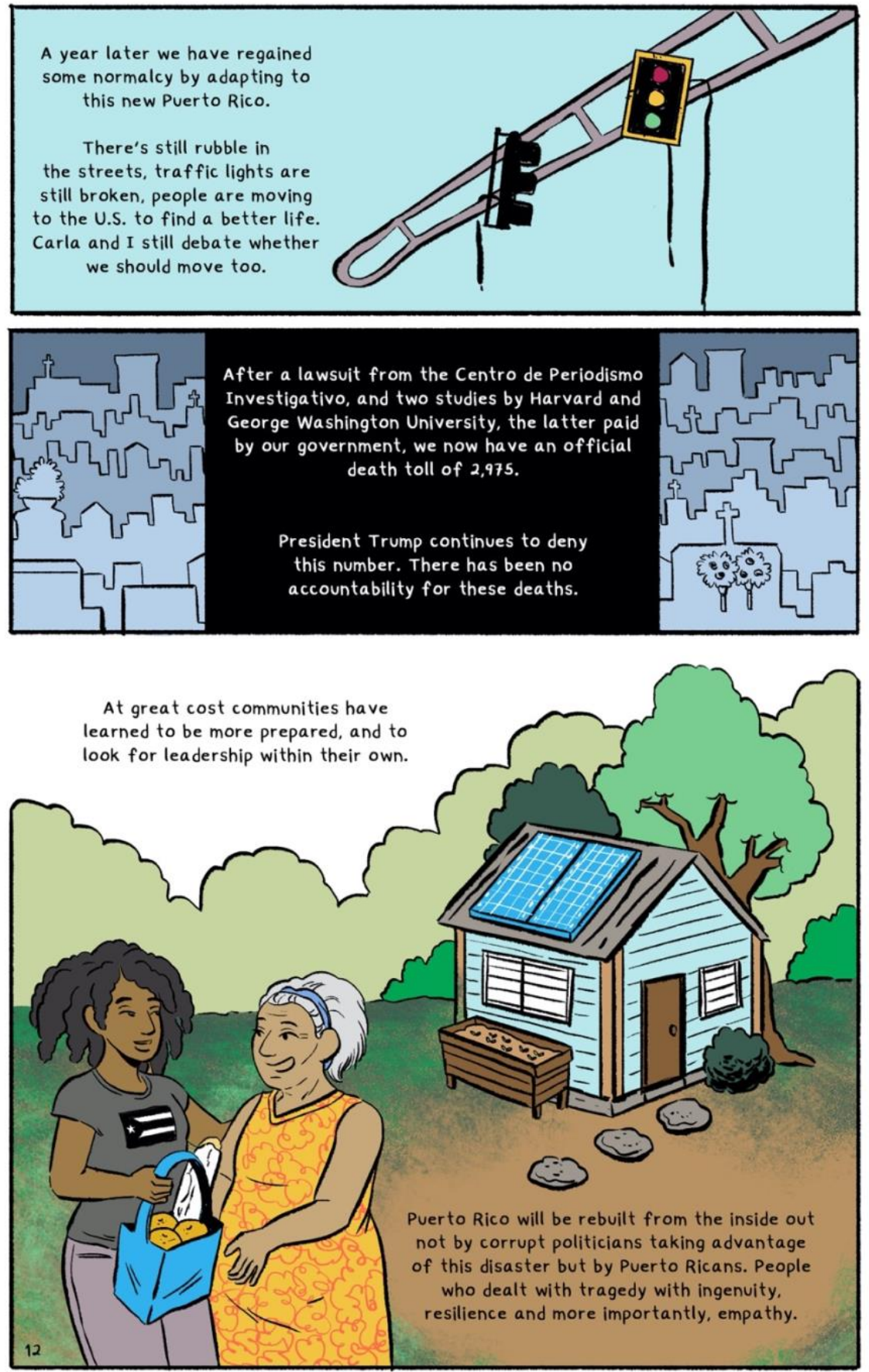

This comic proposes grassroots activism with an eco-friendly message. From María, by R. Colón, 2018, Soda Pop Comics. Copyright 2018 by Soda Pop Comics. Reprinted with permission. 
eTropic 20.2 (2021) Special Issue: Tropical Imaginaries and Climate Crisis

One Spanish-language anthology was Soda Pop Comics' Nublado: Escombros de María (2018). This short collection featured thirteen authors who wrote short, blackand-white comic strips about their experiences with the hurricane and its aftermath. Many focused on themes of migration, ${ }^{10}$ interactions with US figureheads, ${ }^{11}$ and the silence and darkness which linger after the storm. ${ }^{12}$ Two stories offer optimism towards the future, but fall short of articulating a decolonial future. Luis Rodríguez's "Cosas cayeron" [Things fell], consists of two panels. In the first, a young boy stands in front of a large tree, whose leaves have been stripped off to show barren branches. The crown of the tree is missing, presumably showing the cyclone's ruinous impact. His second panel reveals hope. He writes, "Pero cosas, cosas crecerán" [But things, things will grow]. The use of "but," atypical when starting a sentence, prepares the reader for a statement that contradicts the preceding one. The image follows in line. It is a close up of the first image, zoomed in on the ground beside the standing child. There, with one leaf pointing up in strength, and another pointing down as if weakened, is a young sapling inside of a pot. The child and the sapling mirror each other. Both survived the hardships of María and are symbols of resilience. Similarly, both will be part of the island's future. This optimistic and straightforward message unites nature and humans in rebuilding efforts, creating a reciprocal relationship in which the sapling will need care in its early stages to reward the island later on with the potential for shade, food, or ecological sustainability. Trees help protect against climate change because they store carbon dioxide and release oxygen. In that vein, this sapling represents long-term change and also symbolizes the type of mutually beneficial exchange that would favor the island and differs from the current dynamic between the United States and Puerto Rico.

The second comic is Maelo Cruz's untitled one-page piece that shows a traffic jam in Gurabo, Puerto Rico, in 2017 as drivers attempt to buy gas prior to María touching down. Throughout the six panels, Cruz focuses on one protagonist who is increasingly drenched by rain entering the vehicle. By the time he is able to fill up his car's tank nine hours later, he is an amorphous mass of rainwater. The author uses hyperbole to emphasize the rainfall's intensity - which could also serve to foreshadow the severity of future storms. The only text in the comic comes through the form of a radio disc jockey who contextualizes the storm's impact. In the penultimate panel, Cruz condemns the government for not having the proper resources to manage María. The disc jockey comments that "...sin embargo, no tenemos duda que PR sigue siendo la isla bendecida" [however, we have no doubt

\footnotetext{
${ }^{10}$ Colón (2018b) and González (2018).

${ }^{11}$ Castor (2018) and Robbins (2018).

12 Santiago (2018) and Sáez (2018).
} 
eTropic 20.2 (2021) Special Issue: Tropical Imaginaries and Climate Crisis

that PR will continue being a blessed island] (2018, p. 18). Cruz's ending puts forth confidence in the island's ability to respond. This attitude is juxtaposed with a book that the protagonist is reading in one of the panels: René Marqués's La carreta [The Oxcart], a 1952 play about an agricultural family who, in an intense period of industrialization known as Operation Bootstrap, moves from their country home to San Juan, and from San Juan to New York City in hopes of prosperity. However, with each move, the "better life" they seek becomes more complicated. Correspondingly, the family becomes more disconnected from their traditions and the land, and more inculcated in a capitalist mindset propelled by industry and mechanization. Only with the lead protagonist's death is the family able to return to the island. By evoking Marqués's seminal play in the comic strip, Cruz is warning that migration does not necessarily equate to a "better life" - a relevant message to convey in a moment of intense difficulty. In its place, Cruz offers an affective sentiment toward homeland through the radio announcer's optimism in the final panel in the form of a call to stay and rebuild the island, despite governmental ineptitude. Between the disc jockey and the reference to La carreta, Cruz plays with polyvocality to create a discussion on the benefits of remaining on the island and the negatives of leaving. Furthermore, the storm symbolizes the power that the United States lords over Puerto Ricans. With the protagonist's transformation into an amorphous mass of rainwater, the author suggests that the United States' authority, like the storm, is an overwhelming force that Puerto Rico must resist if the island is to reach its potential.

In Rosaura Rodríguez's self-published graphic novel Temporada (2019), the firstperson narrator's uncertainty imposes itself into the narrative structure. Indeed, the structure of the text is like other graphic novels inasmuch as there is little text on the page and the artwork plays an integral role. Temporada is structured in three parts. Rodríguez's goal in the first part is to demonstrate an inability to communicate due to power outages and to present an inertia to the island's cleanup. The author expresses this inertia by challenging herself to see how many pages she can write "cuando estemos en este limbo" [while we are in this limbo]. The second part reveals a society wrought with school closings, widespread death, and a desire to return to normalcy. Finally, the third part acknowledges the long road ahead to recovery and a desire for accurate information regarding the environmental and societal destruction. However, within those three parts are markers of trauma, such as fragmented and disjointed structure and narration, as outlined by Kaplan (2005, p. 65). For instance, a general lack of a narrative arch gives way to disjointed comments. Statements such as "Cuándo harán saber el conteo de muertes. La cifra real" [When will they know the death count. The real statistic], followed by "la ciudad es salvaje" [the city is 
eTropic 20.2 (2021) Special Issue: Tropical Imaginaries and Climate Crisis

savage], reflect the lack of information due to the temporality of disaster, and also signal a lack of structural cohesion. At the same time, the fragmentation also points to her struggle to process the trauma as the author superimposes form on the content to recreate a sentiment of disruption. In a publication without page numbers and rare punctuation, Rodríguez's narrator recognizes the choppiness of her work: "Empecé pensando que esto sería más narrativo Pero perdí el hilo" [I started thinking that this would be more of a narrative But I lost the thread]. One passage is of particular interest because of its political statement. After describing how ensuing fires destroyed a forest, Rodríguez comments that "Al menos el huracán se llevó el letrero de Ricky" [At least the hurricane took the Ricky billboard]. The criticism of Ricky Rosselló, who served as Governor of Puerto Rico from 2017-2019, predates the text scandal that led to his resignation. The hurricane figuratively washes away the political system, represented by a pro-statehood governor, cleansing the island with a tabula rasa to be remade in the author's vision. However, Temporada does not offer that vision explicitly. Although the graphic novel ends on a pessimistic tone, Rodríguez does point to creativity when confronted with disaster as a sign of hope. One scene depicts a person who has rigged a water filtration system as a viable local option to cope with inadequate freshwater access. The image shows that by pumping the system, as one would peddle a bike, the contaminated water can be purified into drinking water for residents to fill their jugs and carboys. Commonplace in post-María, this type of inventiveness will be paramount as freshwater resources continue to diminish. In a rare moment of pride, Rodríguez writes "El ingenio caribeño es vida" [Caribbean ingenuity is life]. Paired with the commentary on the Ricky Rosselló billboard, Rodríguez's perspective becomes clearer: Puerto Rico's recovery will depend on the community's innovation to rebuild, not on the political system that governs it.

A comparable message to Rodríguez's Temporada can be found in Colón's María (2018a). The comic begins with the hurricane and the ensuing guilt that the two characters feel as survivors with access to supermarkets and gas stations. Like Rodríguez, Colón writes to manage her trauma. Similarities further abound in the criticism of Rosselló and Trump for the mishandling of the recovery efforts. In a precursor of the protests that ousted Rosselló in 2019, Colón (2018a) explicitly condemns the governor for being "sequestered with electricity and air conditioners" (p. 6) while downplaying the magnitude of the disaster alongside Trump (p. 7). By aligning Rosselló with Trump, Colón creates a dichotomy between authorities and people's suffering. In fact, Colón has been intentional with her anti-colonial commentary through webcomics that she has written prior to, and after, María. For instance, Colón (2017) challenges Puerto Rico's status, calling on it to explore 
eTropic 20.2 (2021) Special Issue: Tropical Imaginaries and Climate Crisis

independence. She writes that "Puerto Rico's uncertain status affects everything from how we import goods to how we interact with the global community... It's time for Puerto Rico to thrive on its own terms." Colón (2018c) criticizes the incompetence of FEMA, Rosselló, and the US government for their handling of the situation and seeks new approaches to natural disaster management. When considering Colón's body of work, independence and decolonization through local politics are recurring themes to dismantle corruption on the island.

For Colón, decolonization starts at an organic, grassroots level. The somber tone throughout María, in which she asks if Puerto Rico will ever rise from the rubble, ends optimistically. In her last panel, Colón advocates for the need for local community participation and activism. She writes that "At great cost communities have learned to be more prepared, and to look for leadership within their own" (2018a, p. 12). Here Colón separates herself from Puerto Rico's leaders (notably Rosselló) and calls on Gramscian intellectuals, those organic thinkers of the working class who rely on common sense and folk wisdom to lead the people. She then concludes that "Puerto Rico will be rebuilt from the inside out not by corrupt politicians taking advantage of this disaster but by Puerto Ricans. People who dealt with tragedy with ingenuity, resilience, and more importantly, with empathy" (2018a, p. 12). For her, the hurricane does not necessitate the need to only rebuild the infrastructure of Puerto Rico; it necessitates the need to break from the colonial system which has been set in place and the politicians that are complicit in maintaining it. In that vein, Díaz-Basteris is correct in noting that for Colón, the collective trauma in Puerto Rico did not begin with Hurricane María, but with the United States' invasion of the island in 1898 due to the Spanish-American War and their subsequent ownership of the island stemming from the Treaty of Paris (2019, pp. 17-18). The final panel's image is equally telling for Colón's turn to local leadership, adding an eco-feminist perspective. The image shows a young AfroPuerto Rican woman visiting an elderly woman out in the country. The former brings the latter fresh bread and other foodstuffs, thereby highlighting respect for elders, compassion, and community assistance. In the background is the older woman's house, replete with a small garden. The solar panels atop the roof suggest the search for alternative, eco-friendly forms of energy. The move away from the city to the country continues a recurring trope that re-connects one to the land (as seen through the small raised garden) and seeks a lifestyle apart from the industrialized urban city. Additionally, the young woman is wearing a t-shirt imprinted with the Puerto Rican flag. The black-and-white Puerto Rican flag has become a symbol of anti-colonial resistance to the United States' government both on the island and on the mainland. Created by an all-women artist collective known as La Puerta, the flag 
eTropic 20.2 (2021) Special Issue: Tropical Imaginaries and Climate Crisis

has been widely used in protests since 2016 (Agrelo, 2019). The fact that the character is wearing it reenforces Colón's position toward the United States, and the call for an independent Puerto Rico. The author's choice to use a black-and-white flag symbolically severs the island's relationship with the United States because it breaks from the traditional red, white, and dark blue that the two have shared in common since 1952.

\section{Comic Libre: When Life Imitates Art}

According to Mignolo (2011), decoloniality is "decolonial thinking and doing (p. xxiv, my emphasis), thereby making it both theoretical and actionable. Puerto Rican writers have created a space within comic books to reimagine the island as sovereign through decolonial imaginaries whereby counter-discursive voices participate in the negotiation of political and ecological relationships. While these spaces of resistance have existed in Puerto Rico since their annexation to the United States, the failed recovery efforts after Hurricane María hastened decolonial thinking among comic book writers, prompting them to view the hurricane as an opportunity toward an independent future. Authors' approaches to healing the decolonial wound differed, whether it was themes like technology or nativism presented to Englishspeaking or Spanish-speaking audiences. However, their vision for the island unanimously pointed to green initiatives. A reworked relationship with nature emerged wherein the communities positioned themselves with more autonomy to nurture clean energy, local and traditional food production, and a greater reciprocation with nature. As climatologists warn of increasingly intense tropical storms and rising sea levels, self-reliance may be more important than ever before. The mere fact that many of the comics are set in the future suggests that the island, and to a certain extent the world, has staved off further disasters caused by climate change via these aforementioned methods.

Finally, activism, specifically community-based and grassroots, emerged as the authors demanded to reclaim power from politicians in D.C. and on the island. Though these examples are part of the decolonial imaginary that literature offers, "decolonial doing" took shape in July 2019. In the aftermath of the hurricane, life imitated art when 500,000 demonstrators in Puerto Rico worked in solidarity to oust Ricardo Rosselló amid "Telegramgate", the scandal in which a leaked group text conversation revealed that Rossello and his cabinet members made light of the deaths related to Hurricane María along with homophobic, misogynistic, and racist remarks. Among the thousands of people protesting were women dressed as La Borinqueña. With photos of women dressed as the superhero appearing all over 
eTropic 20.2 (2021) Special Issue: Tropical Imaginaries and Climate Crisis

social media during widespread protests of Rosselló, the futures offered in the graphic novels suddenly had a place in the present. Rossello's ousting was proof of decolonial action as people came together to affirm the marginalized communities that those in power had lambasted. People who have read these comic books are empowered to see a future of their choosing. Miranda-Rodriguez took to the Bronx Free Press the day after Rosselló's resignation to address its importance: "Yesterday was the first true step in the direction towards decolonization and it was led peacefully by a new generation of activists that are part of the Ricanstruction of Puerto Rico. These are the true heroes that we should celebrate" (2019). Through the lens of decoloniality, both producers and consumers of Puerto Rican culture envision an autonomous future for the island that foregrounds self-reliance and renounces dependency. To that end, authors in this study have empowered alternative voices to continue assessing and questioning the island's vulnerability under the United States, thereby empowering communities to foster political and ecological transformation. 
eTropic 20.2 (2021) Special Issue: Tropical Imaginaries and Climate Crisis

\section{References}

Acevedo, N. (2019, July 19). What's behind Puerto Rico's protests, scandal? Here's 5 things to know. NBC News. https://www.nbcnews.com/news/latino/what-s-behind-puertorico-s-protests-scandal-here-s-n1031486

Agrelo, J. (2019, July 4). How a change of color for the Puerto Rican flag became a symbol of resistance. Mother Jones. https://www.motherjones.com/media/2019/07/puertorico-resistance-flag-black-and-white-flag-san-juan-la-puerta-colonial/

Aldama, F. L. (2009). Your brain on Latino comics: From Gus Arriola to los bros Hernandez. University of Texas Press.

Arbino, D. (2017). Half-mast: Shifting landscapes of protest and demilitarization in Vieques. In S. Puri \& L. Putnam (Eds.), Caribbean military encounters (pp. 271-288). Palgrave-Macmillan. https://doi.org/10.1057/978-1-137-58014-6 14

Arbino, D. (2019). "The ugliness of my surroundings": Tip Marugg's Ecogothic Poetics of Isolation. eTropic: Electronic Journal of Studies in the Tropics, 18(1), 125-140. https://doi.org/10.25120/etropic.18.1.2019.3668

Ashcroft, B., Griffiths, G., \& Tiffin, H. (2010). Nativism. In Ashcroft, B., Griffiths, G., \& Tiffin, H. (Eds.), Post-colonial Studies: The Key Concepts ( $2^{\text {nd }}$ ed.), (pp. 143-144). Routledge.

Ayala, C.J. \& Bernabe, R. (2007). Puerto Rico in the American century: A history since 1898. University of North Carolina Press. https://doi.org/10.5149/9780807895535 ayala

Betancourt, D. (2018, March 15). A new comic book anthology raises money for Puerto Rico, telling stories of history and fantasy. Washington Post. https://www.washingtonpost.com/news/comic-riffs/wp/2018/03/15/a-new-comic-bookanthology-raises-money-for-puerto-rico-telling-stories-of-history-and-fantasy/

Castelblanco, F. (2018, October 24). Edgardo Miranda-Rodriguez on La Borinqueña, Wonder-Woman, and Ricanstruction at New York Comic Con 2018. Comicsverse. https://comicsverse.com/edgardo-miranda-rodriguez-nycc2018/

Castor. (2018). Cómo estás? In R. Colón and Y. Santiago (Eds.), Nublado: Escombros de María (pp. 19-22). Soda Pop Comics.

Clark, J. (2018). Sato. Self-published.

Coker, K.J. (2015). James in postcolonial perspective. The letter as nativist discourse. Fortress Press. https://doi.org/10.2307/i.ctt13wwwpg

Colón, R. (2018a). María. Soda Pop Comics.

Colón, R. (2018b). Untitled. In R. Colón \& Y. Santiago (Eds.), Nublado: Escombros de María (p. 2). Soda Pop Comics.

Colón, R. (2018c, September 28). "One year later, Puerto Rico is standing still." The Nib. https://thenib.com/hurricane-María-one-year-later/

Colón, R. (2017, October 16). "Puerto Rico: Should I state, or should I go?" The Nib. https://thenib.com/rosa-colon

Coto, D. (2019, September 20). "Puerto Rico faces slow recovery 2 years after the storm." AP News. https://apnews.com/article/hurricane-María-caribbean-hurricanes-stormspuerto-rico-966a0ad2b5094233a99551843025111f

Cruz, M. (2018). Untitled. In R. Colón \& Y. Santiago (Eds.), Nublado: Escombros de María (p. 18). Soda Pop Comics.

Dawson, R. \& Atchison, D. (2018). ¡Pa’lante! In E. Miranda-Rodriguez (Ed.), Ricanstruction: Reminiscing \& rebuilding Puerto Rico (pp. 14-16). Somos Arte.

Díaz-Basteris, M.F. (2019). Webcomics, huracanes, y colonialismo en Puerto Rico. Alter/nativas: Revista de estudios culturales latinoamericanos 9, 1-24. https://alternativas.osu.edu/assets/files/issue9/ensayos/diaz-final.pdf

Earle, H.E.H. (2017). Comics, trauma and the new art of war. University Press of Mississippi. https://doi.org/10.14325/mississippi/9781496812469.001.0001 
eTropic 20.2 (2021) Special Issue: Tropical Imaginaries and Climate Crisis

Etkin, D. (2016). Disaster theory: An interdisciplinary approach to concepts and causes. Elsevier.

Florido, A. (2019, September 24). 2 Years after Hurricane María hit Puerto Rico, the exact death toll remains unknown. NPR. https://www.npr.org/2019/09/24/763958799/2years-after-hurricane-María-hit-puerto-rico-the-exact-death-toll-remains-unkno Garcia, A.M. (Director). (1982.) La operación [Film]. Latin American Film Project.

García Márquez, G. (1967). Cien años de soledad. Editorial Sudamericana.

González, W. (2018). Untitled. In R. Colón \& Y. Santiago (Eds.), Nublado: Escombros de María (pp. 12-13). Soda Pop Comics.

Guzmán, S. (2018). My beloved Borikén. In E. Miranda-Rodriguez (Ed.), Ricanstruction: Reminiscing \& rebuilding Puerto Rico (pp. 99-104). Somos Arte.

Kaplan, E. A. (2005). Trauma culture: The politics of terror and loss in media and literature. Rutgers University Press.

Knowles, S. (2015). The postcolonial graphic novel and trauma: From Maus to Malta. In A. Ward (Ed.), Postcolonial traumas: memory, narrative, resistance (pp. 83-95).

Palgrave-Macmillan. https://doi.org/10.1057/9781137526434 6

La Borinqueña grant awardees. (2018). La Borinqueña. https://www.laborinquena.com/2018-la-borinquena-grant-awardees

La Borinqueña grants program. (2018). La Borinqueña. https://www.la-borinquena.com/laborinquena-grants-program

Lopez, I. (2008). Matters of choice: Puerto Rican women's struggle for reproductive freedom. Rutgers University Press.

Lugones, M. (2008). The coloniality of gender. Worlds \& Knowledges Otherwise 2, 1-17.

Maldonado-Torres, N. (2007). On the coloniality of being. Cultural Studies 21(2-3), 240-270. https://doi.org/10.1080/09502380601162548

Marqués, R. (1952). La carreta, comedia puertorriqueña en tres actos. Casa Baldrich.

McCaffrey, E. (2002). Military power and popular protest: The U.S. Navy in Vieques, Puerto Rico. Rutgers University Press.

Medina, L. (2014). Nepantla spirituality: My path to the source(s) of healing. In E. Facio \& I. Lara (Eds.), Fleshing the spirit: Spirituality and activism in Chicana, Latina, and Indigenous women's lives (pp.167-185). University of Arizona Press.

Mignolo, W. (2005). The Idea of Latin America. Blackwell.

Mignolo, W. (2007). Delinking. Cultural Studies 21(2-3), 449-514. https://doi.org/10.1080/09502380601162647

Mignolo, W. (2011). The Darker Side of Western Modernity. Duke University Press. https://doi.org/10.2307/j.ctv125jgbw

Mignolo, W. \& Vasquez, R. (2013, July 15). Decolonial aestheSis: Colonial wounds/decolonial healings. Social Text Online.

https://socialtextjournal.org/periscope article/decolonial-aesthesis-colonialwoundsdecolonial-healings/.

Miranda-Rodriguez, E. (2016). La Borinqueña \#1. Somos Arte.

Miranda-Rodriguez, E. (2018a). La Borinqueña \#2. Somos Arte.

Miranda-Rodriguez, E. (2019, July 26). "A new day for Boriken." The Bronx Free Press. https://thebronxfreepress.com/a-new-day-for-borikenun-nuevo-dia-para-boriken/

Morillo, J. (2018). Macondo, Puerto Rico. In M. Lopez, D. Rodriguez, H. Newlevant, D. Ruiz, \& N. Schwartz (Eds.), Puerto Rico strong (pp. 155-162). The Lion Forge.

Nose, I. (2018). It also rains in Puerto Rico. CreateSpace Independent Publishing.

Olmedo, I. (2002). What grandmothers can teach us about Puerto Rican culture and community. Practicing Anthropology, 24(3), 34-38.

https://doi.org/10.17730/praa.24.3.p48417618838481u 
eTropic 20.2 (2021) Special Issue: Tropical Imaginaries and Climate Crisis

Pérez, E. (1999). The decolonial imaginary: Writing Chicanas into history. Indiana University Press.

Quijano, A. (2000). Coloniality of Power, Eurocentrism, and Latin America. (Trans. M. Ennis). Nepantla: Views from the South, 1(3), 533-580. https://doi.org/10.1177/0268580900015002005

Rivera, G. (2018). \#Queerborinegra. In E. Miranda-Rodriguez (Ed.), Ricanstruction: Reminiscing \& rebuilding Puerto Rico (pp. 145-147). Somos Arte.

Rivera, L. (2018). Family ends with me. In M. Lopez, D. Rodriguez, H. Newlevant, D. Ruiz, \& N. Schwartz (Eds.), Puerto Rico strong (pp. 96-101). The Lion Forge.

Rivera-Santana, C. (2020). Aesthetics of disaster as decolonial aesthetics: making sense of the effects of Hurricane María through Puerto Rican contemporary art. Cultural Studies, 34 (3), 341-362. https://doi.org/10.1080/09502386.2019.1607519

Robbins, J. (2018). Presión. In R. Colón \& Y. Santiago (Eds.), Nublado: Escombros de María (pp. 27-30). Soda Pop Comics.

Rodríguez, R. (2019). Temporada. Self-Published.

Román, A. (2018). Thirty years later. In E. Miranda-Rodriguez (Ed.), Ricanstruction: Reminiscing \& rebuilding Puerto Rico (pp. 155-157). Somos Arte.

Rosado, A. A Taino's tale. In M. Lopez, D. Rodriguez, H. Newlevant, D. Ruiz, \& N. Schwartz (Eds.), Puerto Rico strong (pp. 80-85). The Lion Forge.

Sáez, D. (2018). Lo que recuerdo de María. In R. Colón \& Y. Santiago (Eds.), Nublado: Escombros de María (p. 16-17). Soda Pop Comics.

Santiago, Y. (2018). Waking up in darkness. In R. Colón \& Y. Santiago (Eds.), Nublado: Escombros de María (pp. 14-15). Soda Pop Comics.

Shwed, Ally. (2018). La operación. In M. Lopez, D. Rodriguez, H. Newlevant, D. Ruiz, \& N. Schwartz (Eds.), Puerto Rico strong (pp. 101-103). The Lion Forge.

Sou, G. \& Cei Douglas, J. (2019). After María: Everyday recovery from disaster. The University of Manchester Press.

Tarwater, T.J. (2018). Pasitos grandes. In M. Lopez, D. Rodriguez, H. Newlevant, D. Ruiz, \& N. Schwartz (Eds.), Puerto Rico strong (pp. 21-40). The Lion Forge.

Torres, F. L. (2019). Deconstructing the superhero: Interrogating the racialization of bodies using all-new, all-different avengers, Vol. I. In R. Ginsberg \& W. Glenn (Eds.), Engaging with multicultural YA literature in the secondary classroom (pp. 162-170). Routledge. https://doi.org/10.4324/9780429053191-17

Torres, F.L. \& Medina, C.L. (2021). Cuentos combativos: Decolonialities in Puerto Rican books about María. Journal of Literacy Research 53(2), 242-264. https://doi.org/10.1177/1086296X211009294

Tuck, E., \& Yang, K. W. (2012). Decolonization is not a metaphor. Decolonization: Indigeneity, Education \& Society, 1(1), 1-40.

Vargas Morales, T.L. (2003). Señal de primavera. Isla negra.

Ward, A. (2015). Postcolonial traumas: Memory, narrative, resistance. Palgrave-Macmillan. https://doi.org/10.1057/9781137526434

Wuebbles, D.J., Fahey, D.W., Hibbard, K.A., Dokken, D.J., Stewart, B.C., \& Maycock, T.K. (Eds.). (2017). Climate science special report: Fourth national climate assessment, volume I. U.S. Global Change Research Program. https://doi.org/10.7930/J0J964J6

Yeampierre, E. (2018). Bohío Girasol 2050. In E. Miranda-Rodriguez (Ed.), Ricanstruction: Reminiscing \& rebuilding Puerto Rico (pp. 164-169). Somos Arte.

Yglesias, M. (2017, October 9). The Jones Act, the obscure 1920 shipping regulation strangling Puerto Rico, explained. Vox. https://www.vox.com/policy-andpolitics/2017/9/27/16373484/jones-act-puerto-rico. 
eTropic 20.2 (2021) Special Issue: Tropical Imaginaries and Climate Crisis

Dr Daniel Arbino is the Head of Collection Development at the University of Texas at Austin's Nettie Lee Benson Latin American Collection. He holds a PhD from the University of Minnesota in Latin American literatures and cultures (2013) and his research interests include Critical Race Theory and post-colonial articulations in Caribbean and U.S. Latino literatures. His recent publications have appeared in Aztlán: A Journal of Chicano Studies, Chiricú, Label Me Latina/o and eTropic journal. 